\title{
Analisis Hukum Penggunaan Dana Wakaf Tunai Untuk Pembangunan Infrastruktur
}

\author{
Faisal \\ Fakultas Hukum Universitas Muhammadiyah Sumatera Utara \\ Jl. Kapten Mukhtar Basri No. 3, Medan - Sumatera Utara \\ Telp: (061) 6622400, Fax: (061) 6623474, 6631003), Kode Pos 20238 \\ Email: faisal@umsu.ac.id
}

Naskah Diterima: 29-0I-2020, Direvisi: 29-06-2020, Disetujui: 06-07-2020, Diterbitkan: 07-07-2020 DDI: https://dai.org//0.30596/dll.v5i2.4058

\begin{abstract}
Abstrak
Indonesia sebagai negara dengan penduduk muslim yang banyak memiliki potensi yang besar salah satunya dengan wakaf. Wakaf dapat dilaksanakan dengan benda bergerak maupun beda tidak bergerak. Wakaf uang yang termasuk dalam benda bergerak sering disebut dengan wakaf tunai, namun perlu dikaji secara yuridis terkait boleh tidaknya hasil perolehan wakaf dipergunakan untuk pembangunan infrastruktur di bidang fasilitas umum dan fasilitas sosial. Metode penelitian yang digunakan dalam penelitian ini yaitu yuridis normatif. Hasil penelitian menunjukkan bahwa sesuai dengan pendapat ahli, kesepakatan sebagian ulama, fatwa MUI, senada dengan hukum positif yang berlaku, hal itu terbukti melalui Pasal 22 huruf e Undang-Undang Republik Indonesia Nomor 41 Tahun 2004 Tentang Wakaf yang diperjelas dengan Pasal 9 Peraturan BWI Nomor 4 Tahun 2010 Tentang Pedoman Pengelolaan dan Pengembangan Harta Benda Wakaf, bahwa dana wakaf tunai dapat digunakan untuk pembangunan infrastruktur termasuk fasilitas umum dan juga fasilitas sosial. Namun, perlunya wakaf tunai diatur secara khusus mengenai mekanisme pengelolaan wakaf tunai yang dialokasikan untuk pembangunan infrastruktur sehingga memiliki kepastian hukum dan pengelolaan yang jelas.
\end{abstract}

Kata kunci: Wakaf, Tunai, Infrastruktur.

\begin{abstract}
As a large Muslim population country, Indonesia has great potential one of which is waqf. Waqf can be carried out with movable or immovable objects. Money waqf included in movable objects is often referred to as cash waqf, but it needs to be reviewed legally related to whether or not the results of waqf acquisition are used for infrastructure development in the field of public facilities and social facilities. The research method used in this study is juridical normative. The results showed that under expert opinion, the agreement of some scholars, MUI fatwa, in line with the applicable positive law, through Article 22 letter e of the Law of the Republic of Indonesia Number 41 of 2004 concerning Waqf which was clarified by Article 9 of BWI Regulation Number 4 of 2010 concerning Guidelines for the Management and Development of Endowment Property, that cash waqf funds can be used for infrastructure development including public facilities and also social facilities. However, the need for cash waqf is specifically regulated regarding the mechanism of cash waqf management allocated for infrastructure development so that it has legal certainty and clear management.
\end{abstract}

Keywords: Waqf, Cash, Infrastructure. 


\section{PENDAHULUAN}

Wakaf sebagai salah satu sumber dana potensial yang berasal dari umat muslim sehingga harus mendapat perhatian kita bersama. Wakaf dapat diberikan dalam dua bentuk baik dalam wujud benda bergerak maupun tidak bergerak. Untuk wakaf benda bergerak dalam bentuk uang atau yang biasa disebut dengan wakaf tunai memiliki ketentuan dalam hal pengalokasian dananya mengingat potensinya yang cukup besar.

Data dari Badan Wakaf Indonesia dalam (www.republika.com, diakses pada tanggal 01 April 2020) menunjukkan bahwa potensi wakaf di Indonesia yaitu sebesar Rp. 180 triliun/tahun dan yang terealisasi sebesar Rp. 400 miliar. Dan masih terdapat target-target dalam mengupayakan agar wakaf dapat berjalan dengan optimal. Besarnya dana wakaf dan potensinya perlu dikaji mengenai pemanfaatannya agar tepat guna dan memang sesuai koridor dalam pengalokasiannya. Salah satunya yang krusial yaitu tentang penggunaan dana wakaf tunai untuk pembangunan infrastruktur khususnya untuk fasilitas umum. Mengacu pada Pasal 5 Undang-Undang Republik Indonesia Nomor 41 Tahun 2004 Tentang Wakaf (UUW) "wakaf berfungsi mewujudkan potensi dan manfaat ekonomis harta benda wakaf untuk kepentingan ibadah dan untuk memajukan kesejahteraan umum".

Kumulatifnya antara kepentingan ibadah dan memajukan kesejahteraan umum mengarah pada penggunaan dana wakaf yang seharusnya dialokasikan untuk kepentingan rakyat banyak. Wakaf secara bersamaan dan sekaligus harus memenuhi syarat dalam hal untuk kepentingan ibadah dan memajukan kesejahteraan umum, namun belum diatur secara jelas kesejahteraan umum yang dimaksud seperti apa jenis-jenisnya dan juga mengenai dana wakaf tunai orang Islam yang akan dipergunakan untuk fasilitas umum dan fasilitas sosial. Lazimnya poin-poin peruntukkan dana wakaf dipergunakan, sudah diatur dalam Pasal 22 UUW "Dalam rangka mencapai tujuan dan fungsi wakaf, harta benda wakaf hanya dapat diperuntukan bagi :

1. Sarana dan kegiatan ibadah;

2. Sarana dan kegiatan pendidikan serta kesehatan;

3. Bantuan kepada fakir miskin, anak terlantar, yatim piatu, bea siswa;

4. Kemajuan dan peningkatan ekonomi umat; dan/atau

5. Kemajuan kesejahteraan umum lainnya yang tidak bertentangan dengan syariah dan peraturan perundang-undangan.

Dilematikanya ditengah-tengah masyarakat terhadap pro kontranya penggunaan dana wakaf tunai untuk pembangunan infrastruktur sebab selama ini banyak orang mengganggap bahwa wakaf itu biasanya dalam bentuk tanah, mesjid, sekolah, dan lain-lain yang dalam bentuk berwujud sehingga masih banyak yang belum mengetahui mengenai bentuk wakaf tunai dalam bentuk uang dan berbagai macam peruntukkannya.

Spesifiknya belum diatur mengenai penggunaan wakaf khususnya wakaf tunai untuk pembangunan infrastruktur seperti fasilitas umum dan fasilitas sosial. Contoh fasilitas umum seperti halte bus, jalan tol, jembatan, maupun infrastruktur lainnya sedangkan contoh dari fasilitas sosial seperti sekolah, puskesmas, maupun fasilitas lainnya yang dapat dimanfaatkan oleh masyarakat umum. Namun perlu dikaji apakah penggunaan dana wakaf tunai untuk pembangunan infrastruktur tidak bertentangan dengan syariah dan peraturan perundangundangan sebagaimana Pasal 22 huruf e UUW itu, sehingga penulis tertarik untuk membahas tentang “Analisis Hukum Penggunaan Dana Wakaf Tunai Untuk Pembangunan Infrastruktur” 


\section{METODE PENELITIAN}

Penelitian ini menggunakan metode penelitian yang mengarah pada yuridis normatif. Menurut Marzuki (2014) bahwa penelitian hukum yang mengarah pada yuridis normatif itu digunakan untuk menemukan kebenaran koherensi (Marzuki, 2014, h. 47). Sehingga analisis data yang digunakan yaitu analisis kualitatif dan menggunakan sumber data melalui studi literatur.

\section{PEMBAHASAN DAN ANALISIS \\ Dasar Hukum tentang Wakaf Tunai di Indonesia}

Indonesia yang masyarakatnya mayoritas beragama Islam mengharapkan hal-hal berkaitan dengan hubungan antara sesama juga telah memiliki eksistensi dengan adanya beberapa undang-undang yang mengatur mengenai hukum Islam. Salah satunya adalah pemanfaatan wakaf tunai, yang beberapa dekade terakhir masyarakat yang mengenal wakaf benda tidak bergerak seperti tanah. Sementara ini karena perkembangan jaman, khususnya hukum syariah maka wakafpun mengalami perkembangan yang pesat yakni di bolehkannya wakaf terhadap benda bergerak dalam bentuk tunai khususnya di bidang infrastruktur dan fasilitas umum sebagaimana diatur dalam Undang-Undang No. 41 Tahun 2004 tentang Wakaf.

Selain Undang-Undang Perwakafan yang mendorong umat Islam untuk berwakaf, lebih dulu umat Islam mengikuti Firman Allah SWT yang menjadi alasan bagi umat Islam untuk berwakaf, yaitu "Kamu sekali-kali tidak sampai kepada kebajikan (yang sempurna) sebelum kamu menafkahkan sebagian harta yang kamu cintai. Dan apa saja yang kamu nafkahkan, maka sesungguhnya Allah mengetahui”. (QS : Ali Imran [3]: 92). Kemudian, adanya hadis dari Abu Hurairah ra., sesungguhnya Rasulullah SAW bersabda: "Apabila anak Adam (manusia) meninggal dunia, maka putuslah amalnya, kecuali tiga perkara : shadaqah jariyah, ilmu yang bermanfaat dan anak sholeh yang mendoakan orang tuanya" (HR. Muslim).

Hans Kelsen yang mengutarakan mengenai teori jenjang norma sehingga adanya aturan mulai dari yang tertinggi hingga ke terendah sebagaimana asas lex superior derogate lex inferior sehingga hukum terhadap wakaf di Indonesia pun memiliki kronologis yang berjenjang. Hans Kelsen dalam Maria Farida Indrati Soeprapto (1998) norma-norma hukum itu berjenjang-jenjang dan berlapis-lapos dalam suatu hierarki tata susunan, di mana suatu norma yang lebih rendah berlaku, bersumber, dan berdasar pada norma yang lebih tinggi, norma yang lebih tinggi berlaku, bersumber dan berdasar pada norma yang lebih tinggi lagi, demikian seterusnya sampai pada suatu norma yang tidak dapat ditelusuri lebih lanjut dan bersifat hipotesis dan fiktifm yaitu norma dasar (grundnorm) (Soeprapto, 1998, h. 25).

Pasal 29 ayat (2) Undang-Undang Dasar Negara Republik Indonesia Tahun 1945 mengatur bahwa "Negara menjamin kemerdekaan tiap-tiap penduduk untuk memeluk agamanya masing-masing dan untuk beribadat menurut agamanya dan kepercayaannya itu". Degradasinya hingga peraturan pelaksana dan peraturan instansi terkait pelaksanaan wakaf diakomodir dengan dasar hukum sebagai berikut:

1. Undang-Undang Nomor 41 Tahun 2004 tentang Wakaf

2. Peraturan Pemerintah Nomor 42 Tahun 2006 tentang Wakaf 
3. Peraturan Badan Wakaf Indonesia Nomor 2 Tahun 2010 tentang Tata Cara Pendaftaran Nazhir Wakaf Uang

4. Peraturan Badan Wakaf Indonesia Nomor 4 Tahun 2010 tentang Pedoman Pengelolaan dan Pengembangan Harta Benda Wakaf

5. Peraturan Badan Wakaf Indonesia Nomor 1 Tahun 2008 tentang Prosedur Penyusunan Rekomendasi terhadap Permohonan Penukaran Perubahan Status Harta Benda Wakaf

6. Peraturan Menteri Agama Nomor 73 Tahun 2013 tentang Tata Cara Perwakafan Benda Tidak Bergerak dan Benda Bergerak Selain Uang

7. Peraturan Menteri Agama Nomor 4 Tahun 2009 tentang Administrasi Pendaftaran Wakaf Uang

Sebagaimana dijelaskan di atas, bahwa wakaf selama ini banyak dipahami dalam bentuk benda tidak begerak seperti tanah dan bangunan, namun secara sah menurut undang-undang dapat pula melakukan wakaf sebagian kekayaan berupa harta benda wakaf bergerak, baik berwujud atau tidak berwujud yaitu uang, logam mulia, surat berharga, kendaraan, hak kekayaan intelektual, hak sewa, dan benda bergerak lainnya. Wakaf uang atau wakaf tunai secara khusus diatur dalam Pasal 28 Undang-Undang Nomor 41 Tahun 2004 tentang Wakaf "Wakif dapat mewakafkan benda bergerak berupa uang melalui lembaga keuangan syariah yang ditunjuk oleh Menteri". Perlunya analisis hukum terhadap wakaf tunai untuk pembangunan infrastruktur sehingga dapat dikaji sejauh mana kebolehan atau ketidakbolehan dalam menggunakan dana wakaf sebab sebagaimana Pasal 22 UUW yang pada substansinya bahwa pengalokasian dana wakaf harus sesuai dengan syariah dan perundang-undangan yang berlaku.

\section{Analisis Hukum Penggunaan Dana Wakaf Tunai untuk Pembangunan Infrastruktur}

Indonesia merupakan negara dengan populasi Muslim terbesar di dunia.Bagi masyarakat Muslim di Indonesia, wakaf identik dengan wakaf tanah dan bangunan. Hal ini ditunjukkan melalui data dari BWI (2016) bahwa Indonesia memiliki tanah seluas 4.359.443.170 meter persegi yang tersebar di 435.768 lokasi. Namun pemanfaatan tanah wakaf masih terbatas pada proyek pembangunan fasilitas ibadah seperti pembangunan masjid sebesar $44.3 \%$ dan mushola sebesar 29.50\%.Pemanfaatan wakaf bagi kegiatan sosial atau mu'ammalah hanya sebesar $8.40 \%$. Dari data tersebut, dapat disimpulkan bahwa pemanfaatan tanah wakaf belum mencapai pada tingkat pengelolaan yang produktif.

Pasal 16 Undang-undang Nomor 41 Tahun 2004 tentang Wakaf membagi jenis harta benda wakaf menjadi dua, yaitu benda tidak bergerak dan benda bergerak.Uang digolongkan menjadi salah satu harta benda wakaf bergerak. Dalam perundang-undangan Republik Indonesia melalui Undang-Undang Nomor 41 Tahun 2004 tentang Wakaf, Indonesia bisa menjadikan dana wakaf tunai sebagai sarana pengembangan ekonomi. Badan Wakaf Indonesia (BWI) merupakan sebuah lembaga independen yang membawahi nazhir wakaf nasional yang berdiri sejak tahun 2007 berdasarkan Kepres No. 75/M/2007 Tanggal 13 Juli 2007 tentang Kepengurusan Badan Wakaf Indonesia. Tercatat hingga 19 Oktober 2017, terdapat 187 lembaga nazhir wakaf tunai yang telah resmi terdaftar di BWI (www.republika.co.id, diakses pada tanggal 01 April 2020) 
Hukum positif di Indonesia memperbolehkan wakaf untuk jangka waktu tertentu, hal ini diakomodir oleh Peraturan Menteri Agama Nomor 73 Tahun 2013 Tentang Tata Cara Perwakafan Benda Tidak Bergerak Dan Benda Bergerak Selain Uang:

1. Tanah bersertifikat Hak Milik (WTT);

2. Tanah bersertifikat Hak Guna Bangunan, Hak Guna Usaha atau Hak Pakai di atas Tanah Negara (WT);

3. Tanah bersertifikat Hak Guna Bangunan atau Hak Pakai di atas hak pengelolaan atau hak milik orang lain (WT);

4. Tanah Negara yang di atasnya berdiri bangunan masjid, mushala, dan/atau makam (WTT).

5. Hak milik atas sarusun (WT).

6. Kapal dengan berat lebih 20 ton termasuk wakaf benda tidak bergerak.

7. Wakaf uang tertentu (5 th, 10jt) (PBWI 1/2009)

8. Wakaf uang mauquf alaih muqayyad (1 M)

Selain wakaf di atas, wakaf uang dengan sertifikat wakaf tunai juga manawarkan peluang yang unik untuk membantu masyarakat. Dengan profit dari wakaf tunai, seseorang dapat membantu bantuan yang berharga bagi pendirian ataupun operasionalisasi lembaglembaga pendidikan termasuk masjid, madrasah, rumah sakit, sekolah, kursus, akademi, dan universitas. Pembelian sertifikat ini dapat membantu terlaksananya proyek-proyek pendidikan, riset, keagamaan, kesejahteraan sosial, pengobatan dan perawatan kesehatan untuk orang miskin dan untuk penghapusan kemiskinan. Pada sistem fiskal yang kini berlaku di negara-negara muslim, khususnya di Bangladesh, perpajakan dititikberatkan pada Pajak Tidak Langsung yang sifatnya regresif, yaitu pajak yang menerapkan tarif yang semakin rendah dengan semakin tingginya jumlah penghasilan yang kena pajak. Di Bangladesh, terdapat kurang-lebih 85\% dari total pendapatan pajak pada 1995-1996 berupa pajak tidak langsung. Sebagian besar pajak langsung dapat dikonversikan sebagai bentuk tanggung-jawab sosial melalui penerbitan Sertifikat Wakaf Tunai.Sertifikat tersebut dapat menggantikan sebagian atau seluruh pajak penghasilan untuk pembiayaan pembangunan infrastruktur kemanusiaan dan sosial. Dalam konteks ini, Wakaf Tunai dapat dipandang sebagai bentuk gerakan pembangunan masyarakat dalam mengatasi masalah pendidikan, sosial, dan ekonomi (www.kompasiana.com, diakses pada tanggal 1 April 2020).

Hasil laporan dari BPHN (2019) menyatakan bahwa di Bangladesh perpajakan dititikberatkan pada Pajak Tidak Langsung yang sifatnya regresif, yaitu pajak yang menerapkan tarif yang semakin rendah dengan semakin tingginya jumlah penghsailan yang kena pajak. Di Bangladesh terdapat lebih kurang 85\% dari total pendapatan pajak pada 19951996 berupa pajak tidak langsung. Sebagian besar pajak langsung dapat dikonversikan sebagai bentuk tanggng jawab sosial melalui penerbitan Sertifikat Wakat Tunai.Sertifikat tersebut dapat menggantikan sebagian atau seluruh pajak penghasilan untuk pembiayaan pembangunan infrastruktur kemanusiaan dan sosial. Dalam konteks ini, Wakaf Tunai dapat di pandang sebagai bentuk gerakan pembangunan masyarakat dalam mengatasi masalah pendidikan, sosial, dan ekonomi.

Sejak kekaisaran Turki Utsmani, wakaf telah menghidupi berbagai pelayanan publik, bangunan seni dan budaya. Tidak dipungkiri Turki pernah menangguk masa-masa keemasan, seperti yang tercermin dari berbagai sekolah, masjid, gedung seni, gedung budaya,rumah sakit, perpustakaan, kompleks komersial, hotel, dan sebagainya, yang dapatditentukan hingga 
kini sebagai "monumen hidup". Namun, sangat disayangkan, pada era revolusi Kemal Attaturk di Turki, peran wakaf yang imperatif ini dimandulkan dalam kehidupan sosial masyarakat Turki. Wakaf juga telah memainkan peran penting di Mesir, terutama pada masa elite Mamluk (1250-1517). Wakaf telah berkembang dengan cukup baik, yang tercermin dari pemanfaatan wakaf untuk kesehatan, pendidikan, perumahan, penyediaan makanan dan air, dan tanah pemakaman. Namun, sebagaimana juga di Turki, peran wakaf di Mesir akhirnya runtuh oleh penguasa Gamal bin Abdul Nasser. Bahkan pada kasus al-Azhar, misalnya, masyarakat menilai lembaga ini tidak lagi independen dan juga gagal menjadi penyeimbang bagi kekuasaan (Rozalinda, 2015, h. 251).

Banyak ahli yang menilai, jika dikelola dengan serius, wakaf memiliki potensi menjadi salah satu intsrumen peningkatan kesejahteraan sosial dan ekonomi masyarakat.Tentu pemanfaatan tanah wakaf tidak selalu untuk tujuan pembangunan sarana ibadah, ada juga yang dimanfaatkan untuk pembangunan sarana sosial dan pelayanan kesehatan (Fahham, 2015).

Namun dalam pengelolaannya masih terdapat berbagai macam problematika yang mengarah ke perdata. Mengenai permasalahan keperdataan, Syuhada (2019) menyatakan bahwa "Hubungan antara manusia dengan manusia dalam praktik sehari-hari seringkali dapat menimbulkan hubungan hukum, yang mana dalam hubungan tersebut anatara yang satu dengan yang lainnya akan menimbulkan hak dan kewajiban yang harus dipenuhi oleh para pihak sehingga dalam istilah hukum dikenal hukum perdata materil dan hukum perdata formil. Hukum perdata materil adalah suatu kumpulan dari pada peraturan perundangundangan yang mengatur tentang hak dan kewajiban keperdataan (privat) antara pihak yang satu dengan pihak lainnya, sedangkan hukum perdata formil adalah peraturan perundangundangan yang mengatur tentang pelaksanaan sanksi hukuman terhadap para pelanggar hak-hak keperdataan sesuai dengan hukum perdata materil mengandung sanksi yang sifatnya memaksa" (Syuhada, 2019).

Penyelesaian perkara wakaf dapat diselesaikan di Pengadilan Agama. Lazimnya juga membutuhkan ahli dan saksi dalam proses pembuktiannya bisa saja dihadirkan nadzir, pewakif atau pihak-pihak lain yang berkaitan dengan sengketa wakaf. Mengutip pendapat dari Hari Sasangka dan Lily Rosita "Kekuatan alat bukti keterangan ahli dimana suatu keterangan ahli baru mempunyai nilai pembuktian, bila ahli tersebut disumpah terlebih dahulu sebelum memberikan keterangan, dengan bersumpah baru mempunyai nilai sebagai alat bukti. Apa yang diterangkan oleh seorang ahli adalah merupakan kesimpulankesimpulan dari suatu keadaan yang diketahui sesuai dengan keahliannya, atau dengan kata lain merupakan penilaian atau penghargaan tentang suatu keadaan. Hal ini berbeda dengan keterangan seorang saksi, yang justru dilarang untuk memberikan kesimpulan-kesimpulan, karena saksi hanyalah merupakan pengungkapan kembali fakta-fakta yang oleh saksi dilihat, didengar dan dialami sendiri" (Asmadi, 2018, h. 46).

Pada kenyataanya apabila kepastian hukum dikaitkan dengan keadilan hukum, maka akan kerap kali tidak sejalan satu sama lain. Adapun hal ini dikarenakan di satu sisi tidak jarang kepastian hukum mengabaikan prinsip-prinsip keadilan hukum, sebaliknya tidak jarang pula keadilan hukum menga-baikan prinsip-prinsip kepastian hukum.Apabila dalam praktiknya terjadi pertentangan antara kepastian hukum dan keadilan hukum, maka keadilan hukum yang harus diutamakan.Alasannya adalah, bahwa keadilan hukum pada umumnya lahir dari hati 
nurani pemberi keadilan, sedangkan kepastian hukum lahir dari suatu yang konkrit.kepastian hukum dapat diartikan sebagai sebuah keadaan yang pasti dan sesuai dengan ketetepan serta ketentuan dari tujuan dibentuknya suatu hukum. Kepastian hukum erat kaitannya dengan rasa aman dan nyaman, sebab hakikat dari kepastian hukum adalah menimbulkan kepastian terhadap segala sesuatu yang menyangkut keraguan, ketidakpastian dan rasa ketakutan yang bersifat manusiawi. Lebih jauh lagi, kajian tentang kepastian hukum erat kaitanya dengan kajian suatu keabsahan.Kaadaan yang pasti dinilai sebuah keadaan yang sah menurut peraturan peundang-undangan baik secara formil maupun materil (Ramadhani, 2017, h. 144).

Pemerintah telah mengeluarkan undang-undang yang mengatur masalah perwakafan namun praktik wakaf yang terjadi dalam kehidupan masyarakat belum sepenuhnya berjalan tertib dan efesien, sehingga dalam berbagai kasus harta benda wakaf tidak terpelihara sebagaimana mestinya, telantar atau beralih ketangan pihak ketiga dengan cara melawan hukum keadaan demikian,tidak hanya karena kelalaian atau ketidakmampuan nadzhir dalam mengelola dan mengembangkan harta benda wakaf tetapi juga karena sikap masyarakat yang kurang peduli atau belum memahami status harta benda wakaf yang seharusya dilindungi demi untuk kesejahteraan umum sesuai dengan tujuan, fungsi, dan peruntukan wakaf (Faisal, 2018).

Dukungan kuat untuk memberdayakan wakaf uang terbuka lebar dengan disahkannya Undang-Undang Nomor 41 Tahun 2004 tentang Wakaf dan Peraturan Pemerintah Nomor 42 Tahun 2006 tentang Peraturan Pelaksana Undang-Undang Nomor 42 Tahun 2006 tentang Wakaf. Paling tidak kepastian hukum mengenai operasional dan tata kelola wakaf uang sudah kuat (Rozalinda, 2015, h. 365).

Penerapan wakaf uang sebagai salah satu bentuk wakaf produktif pada masa sekarang akan mempunyai keunggulan yang lebih besar dari wakaf tradisional, yaitu benda bergerak atau tidak bergerak. Identik di masyarakat apabila dikatakan harta wakaf, maka akan langsung dihubungkan dengan sekolah, rumah sakit dan atau kuburan. Secara umum, wakaf benda bergerak atau tidak bergerak hanya dapat dilakukan oleh orang yang memiliki harta lebih.Hal inilah yang menyebabkan kekayaan wakaf di Indonesia masih sedikit.Selain karena jumlah harta wakaf yang masih sedikit, pengelolaannya pun masih belum menerapkan manajemen modern. Sedangkan wakaf uang dapat dilakukan banyak orang, meskipun tidak kaya. Seseorang dapat berwakaf uang sebesar Rp. 100.000,-. Beberapa negara yang menganut negara kesejahteraan (welfare state) selama ini telah memberikan jaminan sosial dalam bentuk bantuan asuransi sosial kepada penduduk negaranya.Dengan adanya jaminan sosial dapat menunjang pembangunan nasional yang berkesinambungan.Apabila negara masih belum mampu membiayai suatu jaminan sosial kepada masyarakatnya, maka harus didukung dengan sub-sistem lain, hal inilah yang menempatkan wakaf sebagai salah satu sub-sistem pendukung negara untuk memberikan jaminan sosial. Sistem perwakafan dapat dilakukan sebagai alternatif yang mungkin dalam merealisasikan jaminan sosial. Hal ini seiring dengan telah disahkannya Undang-Undang Nomor 41 Tahun 2004 tentang wakaf, yang telah mengamanatkan kepada Badan Wakaf Indonesia agar mengelola harta benda yang berskala nasional dan internasional. Secara mendasar, perwakafan mengharuskan pokok harta tersebut kekal dan abadi, sehingga dikelola dan hasilnya diperuntukkan bagi program jaminan sosial termasuk bagi pemberdayaan masyarakat (Arif, 2012). 
Kegagalan di dalam pelaksanaan hukum adalah bahwa ketentuan-ketentuan hukum yang telah ditetapkan tidak mencapai maksudnya atau tidak berhasil di dalam implementasinya.Konsep Anthony Allot tentang efektivitas hukum difokuskan pada perwujudannya. Hukum yang efektif secara umum dapat membuat apa yang dirancang dapat diwujudkan dalam kehidupan sosial kemasyarakatan. Dengan mengungkapkan dan menganalisis kedua pendapat di atas maka teori efektivitas hukum adalah "Teori yang mengkaji dan menganalisis tentang keberhasilan, kegagalan dan faktor-faktor yang mempengaruhi dalam pelaksanaan dan penerapannya." (Fajaruddin, 2018).

Pasal 15 UUW "Harta benda wakaf hanya dapat diwakafkan apabila dimiliki dan dikuasai oleh Wakif secara sah. Pasal (3) Benda bergerak sebagaimana dimaksud pada ayat (1) huruf b adalah harta benda yang tidak bisa habis karena dikonsumsi, meliputi; a. uang, $b$. logam mulia, c. surat berharga, d. kendaraan, e. hak atas kekayaan intelektual, f. hak sewa, dan g. benda bergerak lain sesuai dengan ketentuan syariah dan peraturan perundang.undangan yang berlaku".

Peruntukkan wakaf uang yang dalam undang-undang memperbolehkan untuk sarana dan kegiatan ibadah, pendidikan serta kesehatan, fakir miskin, anak terlantar, yatim piatu, bea siswa, kemajuan dan peningkatan ekonomi umat dan/atau kemajuan kesejahteraan umum lainnya yang tidak bertentangan dengan syariah dan peraturan perundang-undangan. Selain peruntukkan wakaf uang dalam undang-undang, terkait keafdolan umat muslim dalam berwakaf yang sudah diatur hukum maka perlu diurai berbagai para ulama mahzab yang menjelaskan tentang syarat-syarat bagi penerima wakaf yaitu (Hujriman, 2018, h. 20-21):

1. Mahzab Hanafi, mensyaratkan agar mauquf'alaih (yang diberi wakaf) ditujukan untuk ibadah menurut pandangan Islam dan menurut keyakinan wakif jika tidak terwujud salah satunya maka wakaf tidak sah.

2. Mahzab Maliki mensyaratkan agar mauquh 'alaih (peruntukan wakaf) untuk ibadat menurut pandangan wakif. Sah wakaf muslim kepada semua syi'ar Islam dan badan-badan sosial umum. Dan tidak sah wakaf non muslim kepada masjid dan syiar-syiar Islam.

3. Mahzab Syafi'i dan Hambali mensyaratkan agar mauquh 'alaih adalah ibadat menurut pandangan Islam saja, tanpa memandang keyakinan wakif. Karena itu sah wakaf muslim dan non muslim kepada badan-badan sosial seperti penampungan, tempat peristirahatan, badan kebajikan dalam Islam seperti masjid. Dan tidak sah wakaf muslim dan non muslim kepada badan-badan sosial yang tidak Islam seperti gereja.

Perbedaan pendapat ulama fikih tentang boleh atau tidaknya berwakaf dengan uang memperlihatkan adanya upaya terus-menerus memaksimalkan hasil dan manfaat harta wakaf. Perdebatan ulama tentang unsur kekal/abadi-nya benda wakaf sebenarnya tidak lepas dari pemahaman mereka terhadap hadis Nabi (habasta ashlaha wa tashadaqta biha) (tahan pokokmua dan sedekahkan hasilnya) mengandung makna yang diwakafkan adalah manfaat benda dan benda itu tahan lama (tidak lenyap ketika dimanfaatkan). Sebenarnya, pendapat ulama yang menekankan, bahwa terlepas dari paradigma tentang konsep wakaf sebagai sedekah jariyah yang pahalanya terus mengalir, maka tentu barang yang diwakafkan itu harus bersifat kekal atau tahan lama (Rozalinda, 2015, h. 35).

Melihat pada sisi filosofis perbedaan pandangan ulama tentang wakaf uang dan nilai gunanya, wakaf uang itu dapat dikembangkan. Pengembangan wakaf uang ini bukan berarti menghilangkan watak keabadian tetapi justru akan memberikan keabadian manfaat 
sebagaimana ulama Syafi'iyah, tetapi justru akan memberikan keabadian manfaat sebagaimana diajarkan dalam hadis Nabi. Untuk menjaga kekekalan nilai uang (walaupun materinya habis ketika dibelanjakan), uang wakaf itu diinvestasikan pada kegiatan ekonomi produktif dengan sistem bagi hasil atau diinvestasikan dalam bentuk wakaf properti. Nilai nominalnya tetap terjaga dan hasil investasinya dapat disalurkan kepada mauquf'alaih (Rozalinda, 2015, h. 35).

Pada dasarnya wakaf diperuntukkan untuk kebaikan secara umum yang dipilih oleh waqif. Dibolehkan baginya berwakaf untuk orang dengan nama atau ciri tertentu. Dibolehkan pula berwakaf secara mutlak hingga bisa mencakup semua jenis kebaikan, yang dinamakan dengan waqf am. Bentuknya bisa berupa wakaf untuk masjid, jembatan, sekolah, fakir miskin, dengan segala dimensinya; ekonomi, sosial, kemanusiaan, lingkungan, agama, dan budaya (Rozalinda, 2015, h. 229).

Pengelompokan berdasarkan spesifikasi mauquf 'alaih, yaitu:

1. Wakaf untuk perorangan, yaitu wakaf yang dimanfaatkan secara langsung dengan cara memberikan pemasukan kepada orang-orang yang membutuhkan, seperti wakaf untuk fakir miskin, anak-anak yatim, para tawanan, dan kelompok marginal (pinggiran).

2. Wakaf untuk fasilitas umum, yang bisa dimanfaatkan oleh masyarakat, seperti masjid, jala, air bersih, dan listrik. Dalam pemanfaatannya sama antara yang kaya dan yang miskin.

3. Wakaf berdasarkan aktivitas sosial, yang cukup banyak dalam bentuk organisasi nonpemerintah yang sumber pendanaannya berasal dari wakaf atau sumbangan lain. Di dalamnya juga terdapat bidang yang bisa menjadi tempat penyaluran hasil pengelolaan wakaf atau sumbangan lain. Bidang-bidang tersebut adalah a. layanan agam b. layanan kesehatan, c.layanan pendidikan, d. layanan kemanusiaan, e. fasilitas umum, f. solusi bagi pengangguran, g. pemeliharaan lingkungan, h. Politik dan hak asasi manusia (Rozalinda, 2015, h. 231-232).

Manajemen lembaga wakaf menjadi bagian yang paling krusial dalam memahami persoalan wakaf. Manajemen wakaf berkaitan dengan nazhir selaku pengelola wakaf, sistem pengelolaan wakaf di Indonesia lebih banyak dikelola oleh perseorangan (66\%) daripada organisasi (16\%) dan badan hukum (18\%). Selain itu, harta wakaf juga lebih banyak yang tidak menghasilkan (77\%) daripada yang menghasilkan atau produktif (23\%). Hasil survei ini menunjukkan, dibandingkan nazhir wakaf perseorangan, dalam berbagai aspek ditemukan, bahwa pengelolaan wakaf berbasis organisasi dan badan hukum secara umum lebih memungkinkan untuk diupayakan ke arah pengembangan wakaf (Rozalinda, 2015, h. 250).

Sesuai dengan Fatwa Majelis Ulama Indonesia (MUI) tertanggal 26 April 2002 diterangkan bahwa wakaf uang (cash wakaf/waqf al Nuqud) adalah wakaf yang dilakukan seseorang, kelompok orang, lembaga atau badan hukum dalam bentuk uang tunai. Termasuk ke dalam pengertian uang adalah surat-surat berharga (Ansari, 2006, h. 90).

Pada tahun 2002, Majelis Ulama Indonesia (MUI) telah menetapkan fatwa yang membolehkan wakaf uang. Ketua MUI, KH. Ma'ruf Amin, menyatakan wakaf uang adalah sesuatu yang memiliki nilai yang di wakafkan untuk kepentingan masyarakat,"Dulu wakaf uang diperdebatkan tapi kini tidak lagi, yang penting 'ain-nya tidak berkurang dan nilainya tetap, bisa dipertahankan". KH.Ma'ruf Amin menambahkan tidak ada batas minimal atau maksimal besaran wakaf uang. Yang penting, uang itu milik sendiri dan didapat dengan cara yang halal. Wakaf uang di Indonesia saat ini dari segi infrastrukturnya telah lengkap dan 
tinggl pelaksnaannya karena semuanya telah di atur secara terperinci dalam perundangundangan tentang Wakaf. Wakaf uang di Indonesia, yang telah diakomodir dalam UndangUndang Nomor 41 Tahun 2004 tentang Wakaf bukan hanya membawa perubahan paradigma dan kebijakan wakaf yang revolusioner, responsif dan modern sesuai kemajuan zaman, tetapi juga dia mengandung potensi ekonomi yang luar biasa besarnya yang dapat mensejahterakan umat, bangsa dan negara Indonesia. Wakaf uang ini di lihat dari infrastruktur, instrumen dan perangkat lainnya semuanya telah ada serta di ketahui oleh public (BPHN, 2019).

Pengelolaan dan pengembangan wakaf uang diatur dalam Pasal 7 Peraturan Badan Wakaf Indonesia Nomor 4 Tahun 2010 tentang Pedoman Pengelolaan dan Pengembangan Harta Benda Wakaf ayat:

1. Pengelolaan dan pengembangan wakaf uang hanya dapat dilakukan melalui investasi pada produk-produk LKS dan/atau instrumen keuangan syariah.

2. Dalam hal LKS-PWU menerima wakaf uang untuk jangka waktu tertentu, Nazhir hanya dapat melakukan pengelolaan dan pengembangan di LKS-PWU dimaksud.

3. Pengelolaan dan pengembangan wakaf uang pada bank syariah yang telah dijamin oleh lembaga penjamin simpanan.

4. Pengelolaan dan pengembangan wakaf uang dapat dilakukan dalam bentuk investasi di luar produk-produk LKS atas persetujuan dari BWI.

5. Persetujuan sebagaimana dimaksud pada ayat (4) diberikan setelah terlebih dahulu BWI melakukan kajian atas kelayakan investasi dimaksud.

6. Pengelolaan dan pengembangan wakaf uang dalam bentuk investasi selain pada bank syariah harus diasuransikan pada asuransi syariah.

7. Sebaran investasi harta dalam bentuk wakaf uang (portofolio wakaf uang) dapat dilakukan dengan ketentuan 60\% (enam puluh perseratus) investasi dalam instrumen LKS dan $40 \%$ (empat puluh perseratus) di luar LKS.

Ernawan (2016) menyatakan bahwa BWI melalui peraturannya tentang pedoman pengelolaan dan pengembangan harta benda wakaf bergerak berupa uang mengatur tentang investasi wakaf tunai sebagai berikut:

1. Investasi Wakaf Uang ditujukan untuk proyek-proyek produktif bagi kemaslahatan umat melalui investasi secara langsung dan tidak langsung.

2. Investasi secara langsung adalah investasi pada proyekproyek yang dikelola oleh Nazhir.

3. Investasi secara tidak langsung adalah investasi melalui lembaga yang memenuhi kriteria kelayakan kelembagaan dan menguntungkan

4. Investasi Wakaf Uang dapat dilakukan melalui deposito di Bank Syariah dengan ekspektasi bagi hasil yang paling menguntungkan.

Implementasi wakaf uang melibatkan institusi/lembaga keuangan, yaitu perbankan syariah. Dalam praktek, perbankan syariah tidak dapat membuat produk sebelum mendapat izin dari Bank Indonesia (BI), BI tidak menizinkan sebuah produk sebelum jelas standar operasioal dan prosedurnya, dan BI secara umum tidak akan mengeluarkan izin sebelum terbentuk peraturan negara berupa Peraturan Bank Indonesia (PBI) atau Surat Edaran Bank Indonesia. Oleh kafrena itu masih di perlukan instrumen hukum guna mengimplementasikan wakaf uang; yaitu: (BPHN, 2019)

2. Fatwa dari DSN-MUI tentang Pengelolaan Wakaf uang

3. PBI-SEBI, dan 
4. Standart Operational Prosedur (SOP) bank yang bersangkutan.

Tujuan hukum dan wujud keadilan menurut Jeremy Bentham adalah untuk mewujudkan the greatest happiness of the greatest number (kebahagiaan yang sebesar-besarnya untuk sebanyak-banyaknya orang). Tujuan perundang-undangan menurut Bentham adalah untuk menghasilkan kebagiaan bagi masyarakat. Untuk itu perundang-undangan harus berusaha untuk mencapai empat tujuan yaitu: (Prasetyo, 2012, h. 111-112).

1. To provide subsistence (untuk memberi nafkah hidup)

2. To provide abundance (untuk memberikan makanan yang berlimpah)

3. To provide security (untuk memberi perlindungan)

4. To attain equity (untuk memberi persamaan)

Pada dasarnya tujuan wakaf uang adalah: (Ansari, 2006, h. 97).

1. Melengkapi perbankan Islam dengan produk wakaf uang yang berupa suatu sertifikat berdenominasi tertentu yang diberikan kepada wakif sebagai bukti keikutsertaan.

2. Membantu penggalangan tabungan sosial melalui Sertifikat Wakaf Tunai yang dapat di atas namakan orang-orang tercinta baik yang masih hidup maupun yang telah meninggal sehingga dapat memperkuat integrasi kekeluargaan di antara umum.

3. Meningkatkan investasi sosial menjadi modal sosial dan membantu pengembangan pasar modal sosial.

4. Menciptakan kesadaran orang kaya terhadap tanggungjawab sosial mereka terhadap masyarakat sekitarnya sehingga keamanan dan kedamaian sosial dapat tercapai.

Hukum terkait wakaf tunai harus memberikan manfaat dan kebahagiaan bagi banyak orang sehingga tercapai tujuannya yaitu untuk ibadah dan kesejahteraan umum. Mengaitkan fatwa MUI yang memperbolehkan wakaf uang atau wakaf tunai untuk pembangunan infrastruktur. Dalam hierarki perundang-undangan fatwa MUI tidak memiliki daya mengikat tetapi berdasarkan Peraturan Presiden Nomor 151 Tahun 2014 tentang Bantuan Pendanaan Kegiatan Majelis Ulama Indonesia, yang pada substansinya memuat bahwa MUI sebagai tempat ulama bermusyawarah guna untuk adanya kejelasan dalil melalui ijtima' ulama terhadap suatu hal. Namun, perlu menjadi perhatian kita bersama bahwa, selama fatwa itu tidak dipositifkan secara jelas di Indonesia maka belum memiliki legalitas untuk dilaksanakan. Misalnya, fatwa MUI memperbolehkan dana wakaf tunai untuk pembangunan infrastruktur, namun dalam ketentuan peraturan perundang-undangan belum mengatur tentang kebolehan alokasi itu sehingga perlu diperjelas agar tidak menjadi sebuah dilema. Terlebih lagi, dana wakaf tunai yang sangat potensial ini harus dikelola secara baik oleh pihak terkait sehingga manfaatnya dapat benar-benar dirasakan oleh masyarakat banyak.

Manfaat yang dapat diperoleh dari wakaf uang dibandingkan dengan wakaf benda tetap lainya, antara lain: (Ansari, 2006, h. 97).

1. Wakaf uang jumlahnya bisa bervariasi sehingga seseorang yang memiliki dana terbatas sudah bisa mulai memberikan dana wakafnya tanpa harus menungg menjadi tuan tanah terlebih dahulu;

2. Melalui wakaf uang, asset-aset wakaf yang berupa tanah-tanah kosong bisa mulai dimanfaatkan dengan pembangunan gedung atau diolah untuk lahan pertanian.

Adapun khusus wakaf uang, setidaknya terdapat empat manfaat utama dari wakaf tunai dewasa ini dalam mewujudkan masyarakat yang berkeadilan sosial. Pertama, wakaf uang jumlahnya bisa bervariasi sehingga seseorang yang memiliki dana terbatas sudah dapat mulai 
memberikan dana wakafnya tanpa harus menunggu menjadi tuan tanah dahulu. Kedua, melalui wakaf uang, aset-aset wakaf yang berupa tanah-tanah kosong bisa mulai dimanfaatkan dengan pembangunan gedung atau diolah untuk lahan pertanian. Ketiga, dana wakaf uang juga bisa membantu sebagian lembaga-lembaga pendidikan Islam yang aliran dananya terkadang kembang-kempis dan menggaji civitas akademika seadanya. Keempat, pada gilirannya umat Islam dapat lebih mandiri dalam mengembangkan dunia pendidikan tanpa harus terlalu bergantung pada anggaran pendidikan dan sosial negara yang sangat terbatas (Hasan, 2010),

Selain di atas, ada tiga filosofi dasar, seperti diungkapkan yang harus ditekankan ketika umat Islam akan menerapkan prinsip wakaf uang. Pertama, alokasi wakaf uang harus dilihat dalam bingkai proyek yang terintegrasi, bukan bagian-bagian dari biaya yang terpisah-pisah. Contohnya, anggapan dana wakaf akan habis (musnah) bila dipakai untuk membayar gaji pegawai sementara wakaf harus abadi. Dengan bingkai proyek, sesungguhnya dana wakaf akan dialokasikan untuk programprogram pendidikan dan sosial dengan segala macam biaya yang terangkum di dalamnya. Kedua, asas kesejahteraan nadzir, sudah lazim kita dengar bahwa nadzir seringkali diposisikan kerja asal-asalan dan lillahi ta'ala (dalam pengertian sisasisa waktu dan bukan perhatian utama) dan wajib berpuasa. Sebagai akibatnya, sering kali kinerja nadhir asal jadi saja. Sudah saatnya, nadhir menjadi sebuah profesi yang memberikan harapan kepada lulusan terbaik umat dan profesi yang memberikan kesejahteraan, bukan saja di akhirat, namun juga di dunia. Di Turki, sebagai misal, badan pengelola wakaf mendapatkan alokasi 5\% dari net income wakaf. Sementara itu, The Centre Waqf Council India mengalokasikan dana sekitar $6 \%$ dari net income pengelolaan wakaf untuk kebutuhan operasional. Ketiga, asas transparansi dan akuntabilitas di mana badan wakaf dan lembaga yang dibantunya harus melaporkan setiap tahun akan proses pengelolaan dana kepada umat dalam bentuk audited financial report termasuk kewajaran dari masing-masing pos biaya (Hasan, 2010).

Peraturan BWI No. 4 Tahun 2010 Tentang Pedoman Pengelolaan dan Pengembangan Harta Benda Wakaf pada Pasal 9 ayat:

1. Penyaluran manfaat hasil pengelolaan dan pengembangan harta benda wakaf secara langsung sebagaimana dimaksud pada Pasal 8 ayat (2) dapat dilakukan apabila memenuhi persyaratan:

a. Program pembinaan dan pemberdayaan masyarakat dijalankan sesuai dengan syariah dan peraturan perundang-undangan;

b. Tepat sasaran;

c. Berdampak pada pengurangan kemiskinan dan membuka lapangan pekerjaan;

d. Program berkesinambungan dan mendorong kemandirian masyarakat.

2. Program pembinaan dan pemberdayaan masyarakat sebagaimana dimaksud pada ayat (1) huruf a antara lain:

a. Program sosial dan umum berupa pembangunan fasilitas umum antara lain jembatan, jalan, mandi cuci kakus umum, dan masjid;

b. Program pendidikan berupa pendirian sekolah dengan biaya murah untuk masyarakat tidak mampu dan pelatihan keterampilan;

c. Program kesehatan berupa bantuan pengobatan bagi masyarakat miskin dan penyuluhan ibu hamil dan menyusui; 
d. Program ekonomi berupa pembinaan dan bantuan modal usaha mikro, penataan pasar tradisional dan pengembangan usaha pertanian dalam arti luas;

e. Program dakwah berupa penyediaan da'i dan mubaligh, bantuan guru, bantuan bagi imam dan marbot masjid.

Penggunaan dana wakaf tunai untuk fasilitas sosial dan fasilitas umum telah diatur dalam Pasal 9 ayat (2) Peraturan BWI No. 4 Tahun 2010 Tentang Pedoman Pengelolaan dan Pengembangan Harta Benda Wakaf. Kemudian, jika diperbolehkan untuk pembangunan infrastruktur di bidang fasilitas sosial dan fasilitas umum belum pula diatur mengenai pengelolanya, mekanisme penyerahan dana wakaf tunai kepada Negara, seperti apa pertanggungjawabannya. Sehingga, memiliki kepastian hukum dalam menjalankannya.

\section{KESIMPULAN}

Wakaf tunai diperbolehkan dialokasikan untuk fasilitas umum dan fasilitas sosial, senada dengan fatwa MUI, para ahli dan kesepakatan sebagian ulama, secara regulasi, hukum positif di Indonesia sudah mengatur dalam Pasal 22 huruf e Undang-Undang Republik Indonesia Nomor 41 Tahun 2004 Tentang Wakaf yang berbunyi "kemajuan kesejahteraan umum lainnya yang tidak bertentangan dengan syariah dan peraturan perundang-undangan" Hal itu sudah diperjelas dalam Pasal 9 Peraturan BWI No. 4 Tahun 2010 Tentang Pedoman Pengelolaan dan Pengembangan Harta Benda Wakaf, yang pada beberapa poinnya mengatur tentang bolehnya hasil pemanfaatan dana wakaf tunai untuk program pembinaan dan pemberdayaan masyarakat dijalankan sesuai dengan syariah dan peraturan perundangundangan serta dialokasikan untuk program sosial dan umum berupa pembangunan fasilitas umum antara lain jembatan, jalan, mandi cuci kakus umum, masjid dan lain-lain. Sehingga dapat disimpulkan bahwa wakaf tunai dapat diberdayakan untuk fasilitas umum dan fasilitas sosial.

\section{SARAN}

Perlunya pengaturan khusus mengenai mekanisme pengelolaan wakaf tunai yang diberdayakan untuk pembagunan infrastruktur sehingga lebih terkendali dan ada kejelasan demi menjamin kepastian hukum serta kepastian terhadap hasil pemanfaatan atas dasar dana wakaf tunai dari pewakif. Kemudian, melalui regulasi, perlu ditentukan suatu lembaga yang berwenang untuk memberikan sosialisasi mengenai wakaf tunai sehingga melalui aturan yang berlaku dan dilaksanakan secara patuh sehingga dapat meningkatkan pendapatan dana wakaf tunai agar lebih optimal. 


\section{DAFTAR PUSTAKA}

Ansari, Abdul Ghofur. (2006). Hukum dan Praktek Perwakafan di Indonesia, Yogyakarta: Pilar Media.

Arif, M. Nur Rianto Al. (2012). Wakaf Uang dan Pengaruhnya terhadap Program Pengentasan Kemiskinan di Indonesia. Indo-Islamika. Vol. 2.

Asmadi, Erwin. (2018). Peran Psikiater Dalam Pembuktian Kekerasan Psikis Pada Korban Tindak Pidana Kekerasan Dalam Rumah Tangga. Delegalata. 3 (1).

Ayu, Diah. "Wakaf Tunai di Negara Lain". Diakses pada tanggal 25 Januari 2020 melalui www.kompasiana.com, (diakses pada tanggal 1 April 2020).

Badan Pembinaan Hukum Nasional Departemen Hukum Dan Hak Asasi Manusia, "Laporan Akhir Pengkajian Hukum Tentang Aspek Hukum Wakaf Uang”. Diakses pada tanggal 25 Januari 2020 melalui www.bphn.go.id.

Ernawan, Dwi Aditya. (2016). Wakaf Tunai Sebagai Sumber Alternatif Permodalan Lembaga Keuangan Mikro Syariah di Indonesia. Journal of Islamic Economics Lariba. 2 (2).

Fadhilah, Umi Nur. "Data Wakaf Tunai di Indonesia dari BWI". diakses pada tanggal 25 Januari 2020 melalui www.republika.co.id. Diakses pada tanggal 01 April 2020).

Fahham, Achmad Muchaddam. (2013). Pengelolaan Wakaf Tunai Di Lembaga Pengelola Wakaf DanPertanahan Pengurus Wilayah Nahdlatul Ulama Daerah Istimewa Yogyakarta (Cash Waqf Management at The Waqf and Land Management Agency Nahdlatul Ulama Special Region of Yogyakarta), Aspirasi. 6 (1).

Faisal. (2018). Akibat Hukum Ketiadaan Akta Ikrar Wakaf Atas Perwakafan Tanah. De Lega Lata Jurnal Ilmu Hukum Fakultas Hukum Umsu. 3 (2). 143-153. https://doi.org/10.30596/dll.v3i2.3154.

Fajaruddin. (2018). Efektivitas Undang-Undang Nomor 33 Tahun 2014 Tentang Jaminan Produk Halal Dalam Perlindungan Konsumen. De Lega Lata Jurnal Ilmu Hukum Fakultas Hukum Umsu. 3 (2). 204-216. Https://doi.org/10.30596/dll.v3i2.3151.

Hasan, Sudirman. (2010). Wakaf Uang dan Implementasinya di Indonesia. Jurnal Syariah dan Hukum, 2 (2).

Hujriman. (2018). Buku Ajar Hukum Perwakafan di Indonesia Suatu Pengantar. Yogyakarta: Deepublish.

Marzuki, P.M. (2005). Penelitian Hukum. Jakarta: Kencana Prenada Media Group.

Prasetyo, Teguh. (2012). Filsafat, Teori, \& Ilmu Hukum Pemikiran Menuju Masyarakat yang Berkeadilan dan Bermartabat. Depok: PT RajaGrafindo Persada.

Ramadhani, Rahmat. (2017). Jaminan Kepastian Hukum Yang Terkandung Dalam Sertipikat Hak Atas Tanah. De Lega Lata. 2 (1). 139-157. https://doi.org/10.30596/dll.v2i1.1144.

Rozalinda. (2015). Manajemen Wakaf Produktif. Jakarta: PT RajaGrafindo Persada.

Soeprapto, Maria Farida Indrati. (1998). Ilmu Perundang-Undangan Dasar-Dasar dan Pembentukannya. Yogyakarta: Kanisius.

Syuhada, Mhd. Teguh. (2019). Pelaksanaan Sita Jaminan Terhadap Objek Sengketa Yang Berada Di Tangan Pihak Ketiga Dalam Penanganan Perkara Perdata. Delegalata. 4 (1). 
Undang-Undang No. 41 Tahun 2004 tentang Wakaf.

Peraturan Menteri Agama Nomor 4 Tahun 2009 tentang Administrasi Pendaftaran Wakaf Uang.

Peraturan Menteri Agama Nomor 73 Tahun 2013 tentang Tata Cara Perwakafan Benda Tidak Bergerak dan Benda Bergerak Selain Uang.

Peraturan Pemerintah No.42 Tahun 2006 tentang Wakaf.

Peraturan BWI No. 2 Tahun 2010 Tentang Tata Cara Pendaftaran Nazhir Wakaf Uang.

Peraturan BWI No. 4 Tahun 2010 Tentang Pedoman Pengelolaan dan Pengembangan Harta Benda Wakaf.

Peraturan BWI Nomor 1 Tahun 2008 tentang Prosedur Penyusunan Rekomendasi terhadap Permohonan Penukaran Perubahan Status Harta Benda Wakaf. 